\title{
JEWELRY OF THE 1980s: A RETROSPECTIVE
}

\author{
By Elise B. Misiorowski
}

Fluctuations in the diamond market brought a new focus in jewelry on small diamonds and colored stones. The large quantities of blue topaz, amethyst, and citrine available made these gem materials especially popular. Cultured pearls saw a phenomenal rise, especially early in the decade. A broad mix of design trends included a return to older metal techniques such as granulation, as well as experimentation in new metals and metal-working techniques. While classical European houses were credited with some important new designs, exciting innovations emerged from elsewhere in Europe as well as Asia and the U.S.

\section{ABOUT THE AUTHOR}

MS. Misiorowski is a research librarian in the Richard T. Liddicoat Gemological Library and Information Center at GIA, Santa Monica, California.

Acknowledgments: The author gratefully acknowledges the following people for their help in preparing this article: Robert Crowningshield and Ron Frankel for research assistance; Licia J. Angino, Dean Barry, Marla Bigeleisen, Kris Carter, Brigitte Devine, Caroline Dougherty, Denise DeLuca, Lillian Guerrero, Emma Kerr-Smiley, Bonnie Kimmel, Katherine Kimmel, D. Korber, Suzanne Mauduit, Susan Meyer, David Morrow, Yumiko L. de Muink Keizer, Golbarg Parstabar, Lynn Ramsey, Teresa Sieg, Usha Subramaniam, and Nina Wahl for their assistance in obtaining illustrations; and Robert Misiorowski, Dona Dirlam, Rose Tozer, Karen Stark, and Robert Weldon for their support during the creative process.

Gems \& Gemology, Vol. 26, No. 1, pp. 76-93

(c) 1990 Gemological Institute of America
$\mathrm{T}$ The 1980s was an exciting, and at times turbulent, era for the gem and jewelry world. In 1980, prices for large, fine diamonds were at an all-time high. The boom, and subsequent bust, of this segment of the diamond market had a profound effect on the jewelry world: It shifted the focus to pearls and colored stones, as well as to smaller, commercial-grade diamonds. The emergence of new cuts for gems, the increased use of pavé- and channelset melee diamonds, and the continued interest in new textures and coloration techniques for metals characterize jewelry of the 1980s. As the decade advanced, the fashion trend of wearing many little items of jewelry gradually changed to wearing fewer but more important pieces that made bolder fashion statements, reflecting the wearer's individual taste and style. In the 1980s, more women than ever before pursued careers and high-profile positions. These women, in buying their own jewelry, became an important new market (Eisman and Hinge, 1988).

Education and the appreciation of tangible assets with lasting quality also influenced the buying decisions of the now more knowledgeable consumer. Gem associations and the international auction houses have played an important role in heightening this awareness. This retrospective, based on a review of major jewelry publications worldwide, examines the key trends in the use of diamonds, colored stones, and precious metals, and highlights some of the designers that advanced these trends in the 1980s.

\section{DIAMONDS}

The year 1980 saw diamond prices fluctuate radically. To steady the market, De Beers cut back on the number of rough diamonds offered to sightholders in larger sizes of good color and clarity (Shor, 1988b). Since melee diamonds were less expensive and more readily available, jewelry designers looked for more ways to use them (figure 1). Pavé and channel settings utilized small diamonds to great advantage. The multi-stone anniversary ring became espe- 
Figure 1. This group of jewelry includes some of the most popular styles introduced in the 1980s. Note especially the various uses of melee diamonds, mabe pearls, freshwater cultured pearls, and colored stones. Shown here are: (top left to right) a multistrand, twisted necklace (torsade) of naturalcolor freshwater cultured pearls with a channel-set sapphire and

diamond clasp; a spool-cut green tourmaline and ancientstyle gold bead necklace; mabe pearl earrings with pavé-set diamonds; (middle left to right) dangling earrings with bezelset, cabochon-cut tourmalines; an ancient-style gold ring set with tourmalines; stackable rings of sapphires, diamonds, and emeralds; a cultured pearl necklace with a centerpiece of diamonds pavé-set around a

3-ct sapphire; (bottom left to right) a bezek-set "tennis" brace-

let; a wide engagement ringwedding band with channel-set baguette diamonds; a 2.53-ct sapphire ring with oval diamonds; a 2.54-ct emerald ring with baguette diamonds channel set down the wide shank;

and a 5.34-ct tanzanite ring with calibrated tsavorite garnets, channel-set baguette diamonds, and pavé-set round diamonds. Jewelry courtesy of The

Collector, Fallbrook and La Jolla, CA; photo (C) Harold \&) Erica Van Pelt.

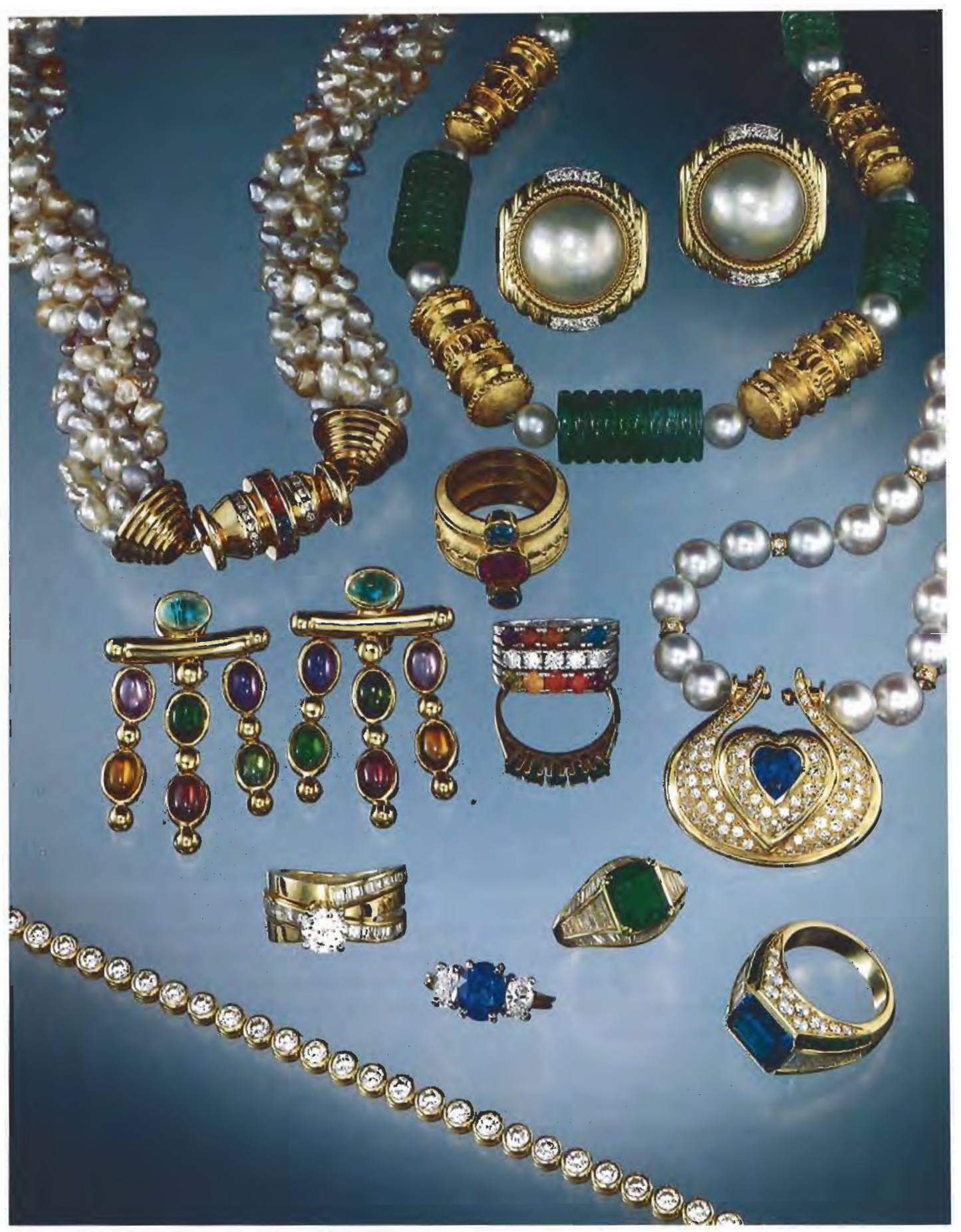

cially popular, as did the tennis bracelet later in the decade. Annual jewelry design competitions offered by the Diamond Information Center-Diamonds Today, Diamonds International, and Diamonds of Distinction-continued to stimulate creative efforts to make the most of diamonds.

The aftermath of the diamond investment fad found buyers more aware of the importance of proportions in cutting (Shor, 1989). Although the round brilliant remained the industry standard, diamond cutters promoted a variety of new cuts designed to maximize weight retention while still producing a pleasing gem. Triangular-shaped brilliants, for example, were developed to make best use of the diamond macle; introduced in the 1970s, the Trilliant and the Trillion, among others, became very popular during the ' 80 s, especially in matched pairs as side stones in a ring to set off an important stone. The Radiant cut, which gave additional life to straight-edge cut diamonds, contributed greatly to the acceptance of fancy-color diamonds, especially yellows and pinks, during the 


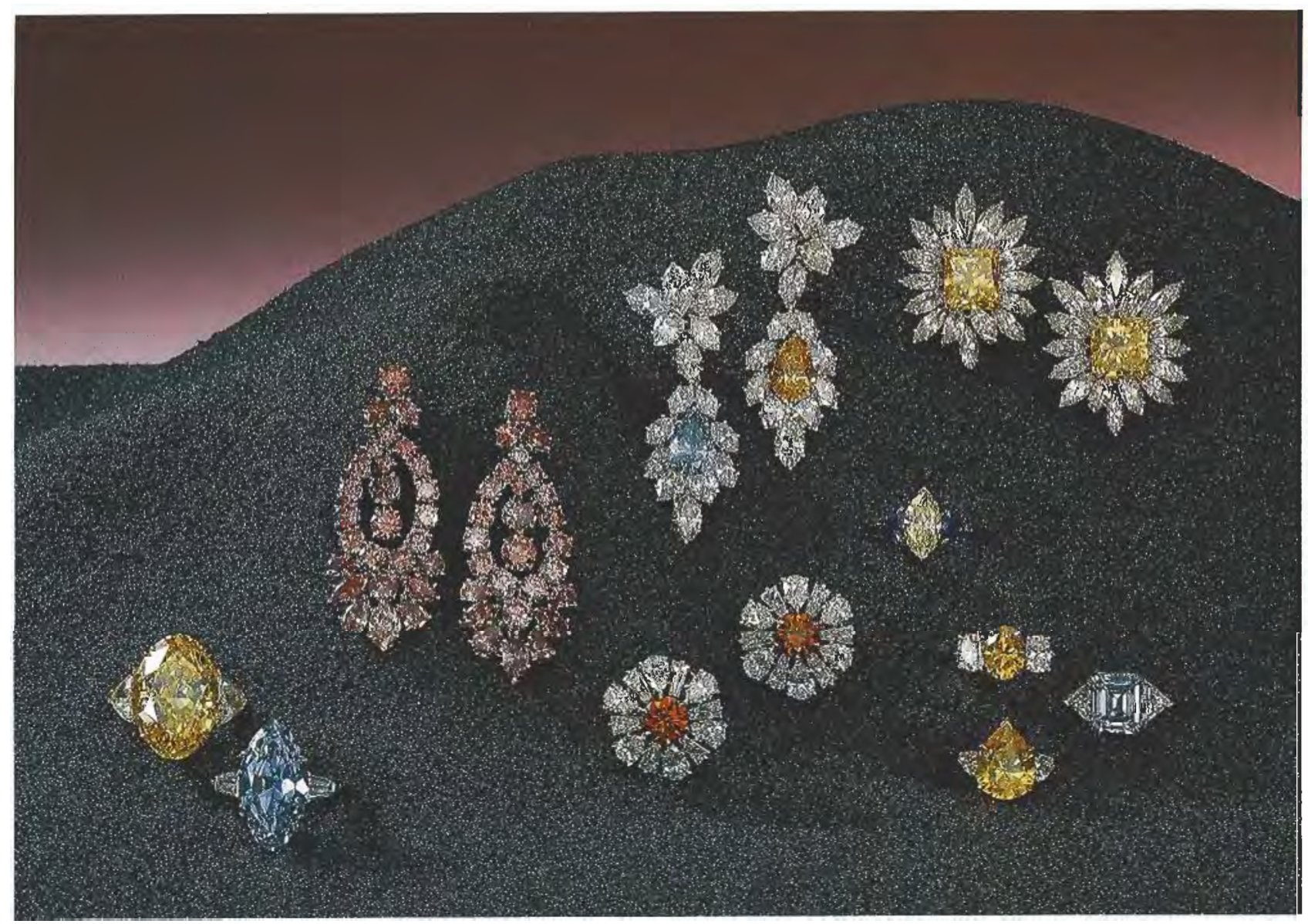

Figure 2. This group of diamond rings and earrings illustrates the increased interest in fancy-color diamonds that arose in the 1980s. All of the pink diamonds in the earrings are from Australia. Note the use of triangular brilliants as side stones for two of the rings, and the "unmatched" pair of earrings, with a 1.90-ct. fancy blue diamond in one and a 2.10-ct. fancy yellow diamond in the other. The largest stone in this photo, the fancy yellow diamond in the ring on the left, is $12.65 \mathrm{ct}$. Courtesy of Harry Winston, Inc.

'80s (R. Crowningshield, pers. comm., 1990). Square-cut brilliant diamonds were developed partly because they could be calibrated to fit snugly in channel settings, and partly because their retention of weight from octahedral rough is considerably greater than for a round brilliant. The Quadrillion, introduced in 1981, and the Princess, introduced in 1984, are two trademarked squarecut brilliants available in the diamond trade.

Later in the decade, the Central Selling Organization commissioned Marcel Tolkowsky's grandnephew, Gabi Tolkowsky, to develop new diamond cuts for odd-shaped and off-color rough. Five cuts were officially presented at the 24 th World Diamond Congress in 1988-Zinnia, Dahlia, Marigold, Sunflower, and Fire Rose ("Clever diamond cuts launched by the CSO," 1988).

The 1980s also saw a renewed interest in fancycolor diamonds (figure 2), stimulated in part by the publicity given to fancy pink diamonds from Australia (see, e.g., Hofer, 1985). The excitement surrounding fancy-color diamonds reached a peak in April 1987, when Christie's auctioned a 0.95-ct fancy purplish red diamond for the unprecedented price of $\$ 926,000$ per carat (Kane, 1987). Large colorless diamonds made a comeback toward the end of the decade and also sold well at auction after 1987. Following their red diamond success, in October 1987 Christie's sold a D-color internally flawless 64.83-ct pear shape for $\$ 6,380,000$. Not to be outdone, in April 1988, Sotheby's auctioned an 85.91-ct D-color internally flawless pear shape for $\$ 10,043,000$.

\section{COLORED GEMSTONE TRENDS}

Colored Stones. Compared to the previous two decades, the 1980s saw a much greater use of colored stones in jewelry. This could be attributed 
to a number of factors in addition to the higher diamond prices mentioned earlier. In 1981, the blue sapphire engagement ring given to Lady Diana Spencer by Charles, Prince of Wales, helped stimulate global interest in colored stones. Education in gemology on the part of both the jeweler and the consumer has generated greater awareness of the many attractive and affordable varieties in the marketplace. As the decade progressed, the availability of many colored stones in larger sizes (e.g., blue topaz, amethyst, and citrinel also met the trend for larger, bolder jewels, thereby satisfying the growing interest in dramatic-colored jewelry. Competitions such as the Spectrum Award, offered annually by the American Gem Trade Association, encouraged jewelry designers to use a greater number and variety of colored stones.

Fine-quality sapphires, rubies, and emeralds maintained their supreme status among colored gems, and as demand increased so did their prices. This stimulated a wider use of more affordable gemstones that, prior to the 1980s, often were purchased only as birthstones. Topaz, amethyst, citrine, and tourmaline experienced the greatest growth, in buyer recognition and salability. In particular, the large quantities of color-enhanced blue topaz that entered the market in the '80s made this gemstone tremendously popular because of the affordable prices. Although the greater supplies provided by enhancements were a significant factor in gemstone marketing during the decade, the public was generally unaware that treatments were involved. In fact, as the decade progressed, heat treatment of corundum put greater numbers of fine blue and yellow sapphires on the market (figure 3), making them more affordable as well.

Tsavorite and rhodolite garnets, as well as tanzanite, were also seen more frequently in jewelry during the ' 80 s (see figure 1). In addition, there was greater use of opaque and translucent gems - such as lapis lazuli, malachite, black onyx, hematite, and jade-for beads, cabochons, and inlay work. Translucent and cryptocrystalline quartz, opal, and tourmaline were also used in this way. Sugilite, the purple opaque-to-translucent by-product of manganese mining in South Africa, was introduced as a gem material during the 1980s (Shigley et al., 1987) and found some popularity, especially in jewelry from the American Southwest.

Organic Gem Materials. More than any other gem during this decade, pearls enjoyed a renaissance of interest. Pearl imports into the U.S. grew from $\$ 80$ million in 1980 to over $\$ 240$ million in 1984 ("Pearl sales up," 1988). Before 1980, cultured pearls were mostly seen as 16-inch single-strand necklaces of graduated or 5- to 6-mm pearls. Into the ' 80 s, opera-

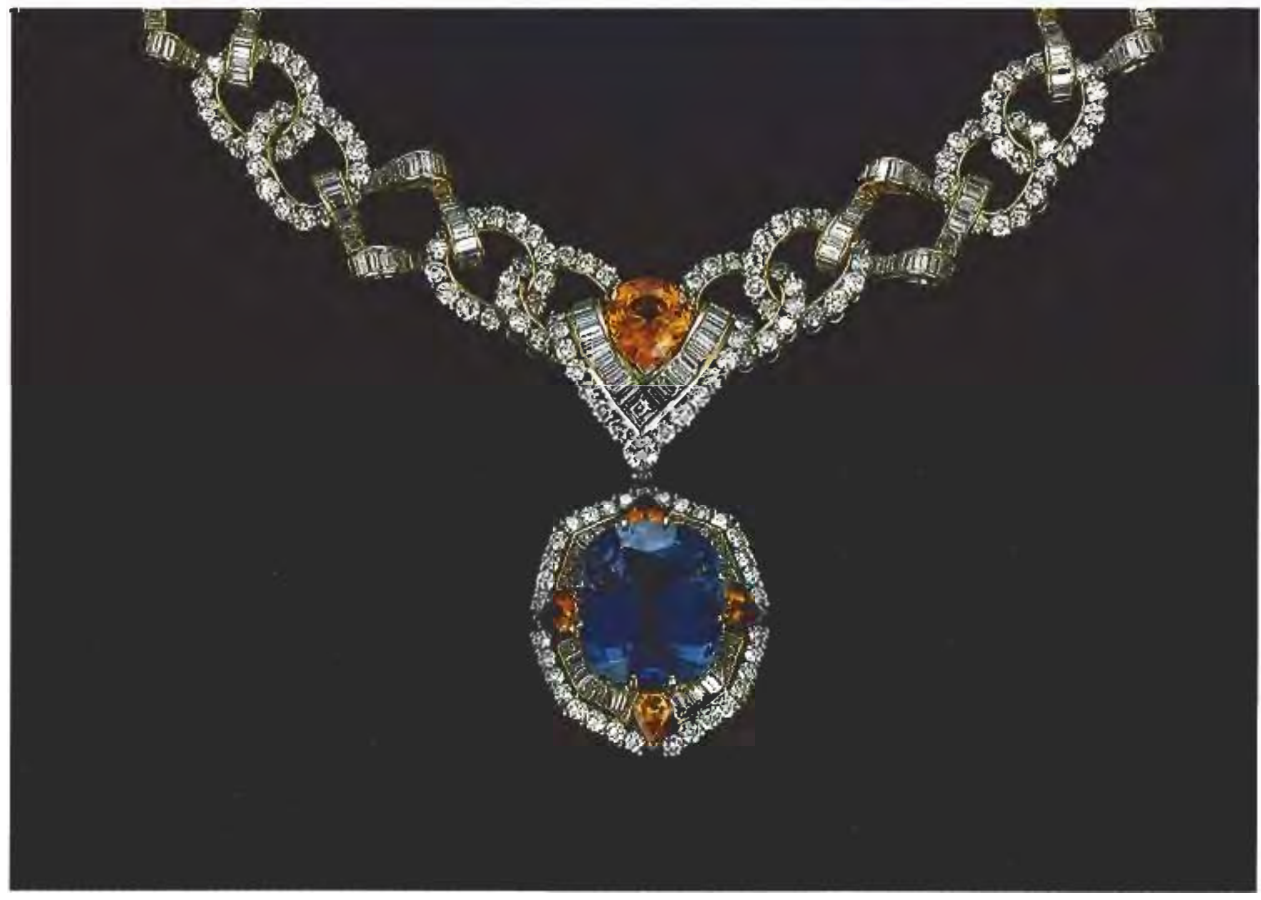

Figure 3. Heat-treated yellow and blue sapphires were commonly seen in the jewelry market during the 1980s. In this fine necklace, they are set off by prong-and channel-set diamonds in yellow and white gold. Courtesy of Gem Source International; photo $\mathbb{C}$ Tino Hammid. 


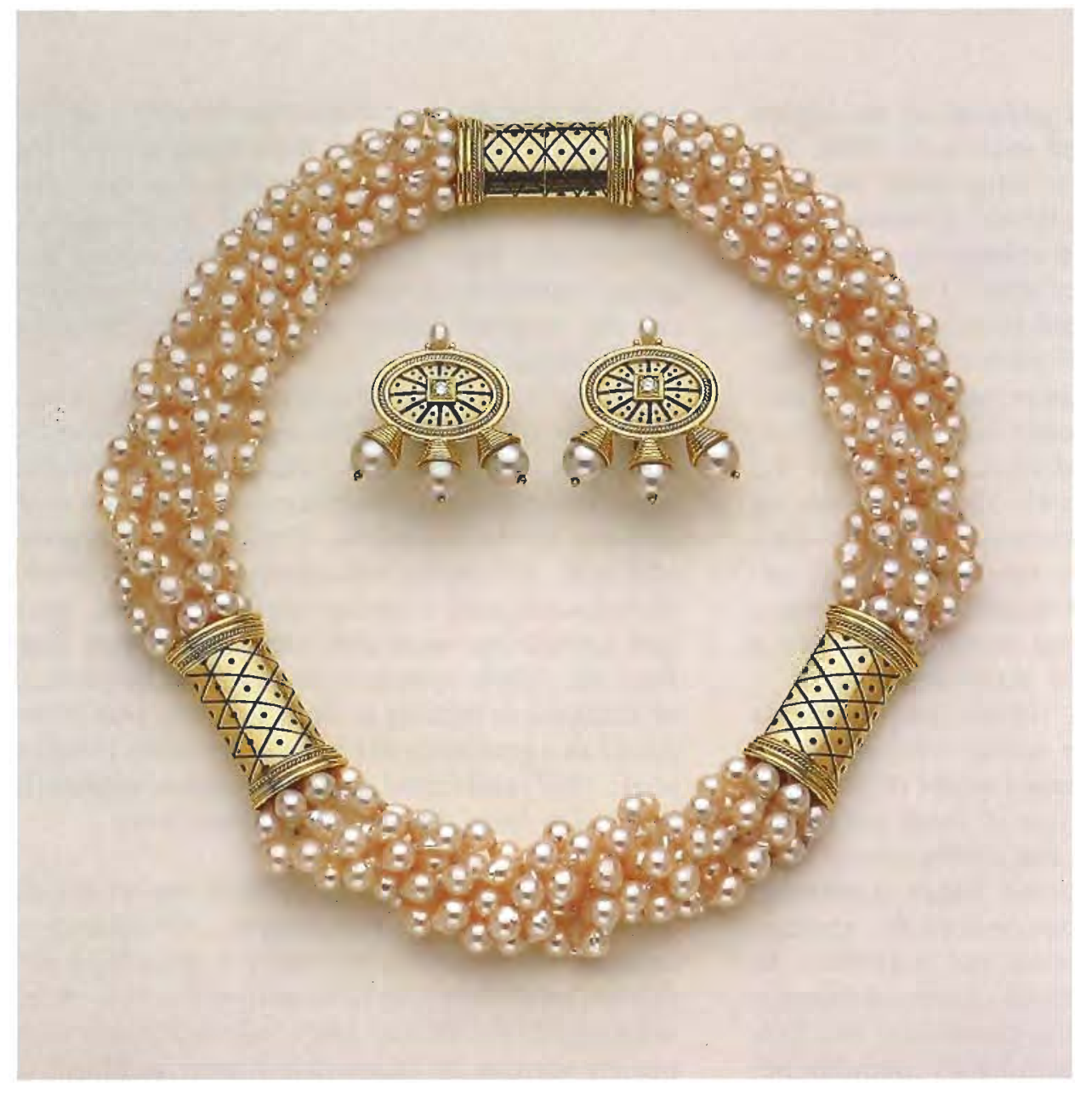

Figure 4. Baroque-shaped cultured pearls gained in popularity during the 1980s, as demand for all pearls grew. The torsade, or twisted choker, a major new style of the 1980 s, used pearls or gem beads. These multiple strands of pink baroque pearls and matching earrings are accented by $18 \mathrm{~K}$ gold "funnels" with back enamel detailing. Jewelry designs (C) Elizabeth Gage, Ltd.

length strands of slightly larger pearls became more common, worn either as one long strand or wrapped twice around the neck. The Pearl Promotion Society's annual pearl jewelry design competitions encouraged new ideas on how to wear pearls, resulting in pearl jewelry that was more versatile and contemporary.

Round, unblemished, saltwater cultured pearls have always commanded a premium price. As demand increased during the '80s, declining production of the finer qualities led to even higher prices. This caused the more affordable baroqueshaped cultured pearls, with their exceptional orient and luster, to gain greater acceptance (figure 4).

Initially harvested in Japan, enormous quantities of freshwater cultured pearls are now coming primarily from China. Besides the white, riceshaped cultured pearls that have appeared in profusion, freshwater cultured pearls come in a variety of baroque shapes and natural pastel colors. Pale pink, peach, apricot, mauve, and lavender have been combined in mixtures of hues (see figure 1), sometimes strung with gold or gemstone beads as accents in the strand.

Naturally colored black pearls, cultured in French Polynesia, were first harvested and sold in the late 1970s but came into their own during the 1980s. These large $(9+\mathrm{mm})$ pearls range in color from silver to black, with a variety of overtones (Goebel and Dirlam, 1989; figure 5). The warm South Seas also favored the cultivation of large (12-19 $\mathrm{mm}$ ) creamy white, yellow, and brownish pearls.

Mabe pearls and cultured blister pearls appeared often in jewelry during the 1980 s. Mabe pearls are ideally suited for the larger look, particularly for earrings (see figure 1). Cultured blister pearls, cut with some of the surrounding mother-of-pearl showing, have been used as the focal point in clasps for twisted pearl necklaces and in dramatic brooches.

Ivory, coral, and tortoise shell have come under scrutiny because of environmental issues. Heavy poaching and smuggling of ivory in recent years severely threatens the African elephant. After 


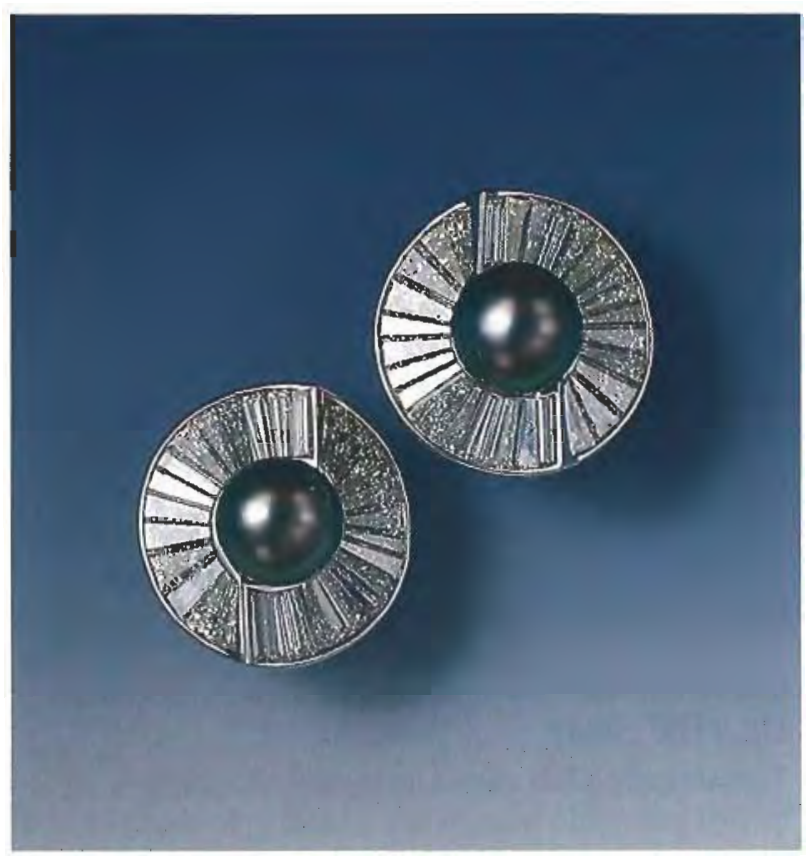

Figure 5. Polynesian black cultured pearls gained great popularity over the course of the decade, especially in fine jewelry. These 11- mm black cultired pearls, surrounded by $10 \mathrm{ct}$ of channel-sèt baguette diamonds, are courtesy of Harry Winston, Inc.

much controversy, the Convention on International Trade in Endangered Species announced in October 1989 that a formal ban on ivory trading had been approved ("Ban on ivory trade gets formal approval," 1989). Because of the negative publicity, consumer interest in jewelry and artifacts of ivory in the U.S. dropped considerably.

Tortoise shell comes from the epidermal layer that covers the shell of the hawksbill marine turtle and has been used for centuries to make jewelry and trinkets. In recent years, due to pollution and overfishing, the hawksbill turtle has been placed on the endangered species list (Weiss, 1988); tortoise shell jewelry and other objects can no longer be imported into the U.S.

Fine coral is becoming harder to find, also due to pollution and overfishing. The Mediterranean, the traditional source for fine "oxblood" red coral, has been seriously depleted. The Sea of Japan now produces most of the coral on the market, with the Taiwanese doing a majority of the harvesting and cutting. As this area, too, is at risk, the Japanese have begun to enforce stricter quotas in these waters (Federman, 1990). Environmental issues are demanding more attention as the 20th century draws to a close. Perhaps the use of organic materials from endangered species will be phased out in the years to come.

New Colored Stone Cuts. During the 1980s, a variety of new cuts for colored stones became popular. The most notable among these is the fantasy cut introduced by German lapidary Bernd Munsteiner (figure 6). The gems, usually transparent, are cut with a free-form outline and given a number of indented, grooved facets, which provide visual texture and interest. Munsteiner, raised in the famous gem-cutting center of Idar-Oberstein, has also been credited with developing the "negative cut" (a cabochon crown with a carved or faceted pavilion; Thomas, 1987). Many other gemcutting artists have followed Munsteiner's lead and have developed their own styles and techniques.

Figure 6. The fantasy cut was initiated by Bernd Munsteiner in the early '80s. These three fantasy-cut ametrines - a pendant and brooch set in $18 \mathrm{~K}$ gold and a sculpture-are examples of Munsteiner's style. Courtesy of H. Stem, New York; photo (C Harold el Erica Van Pelt.

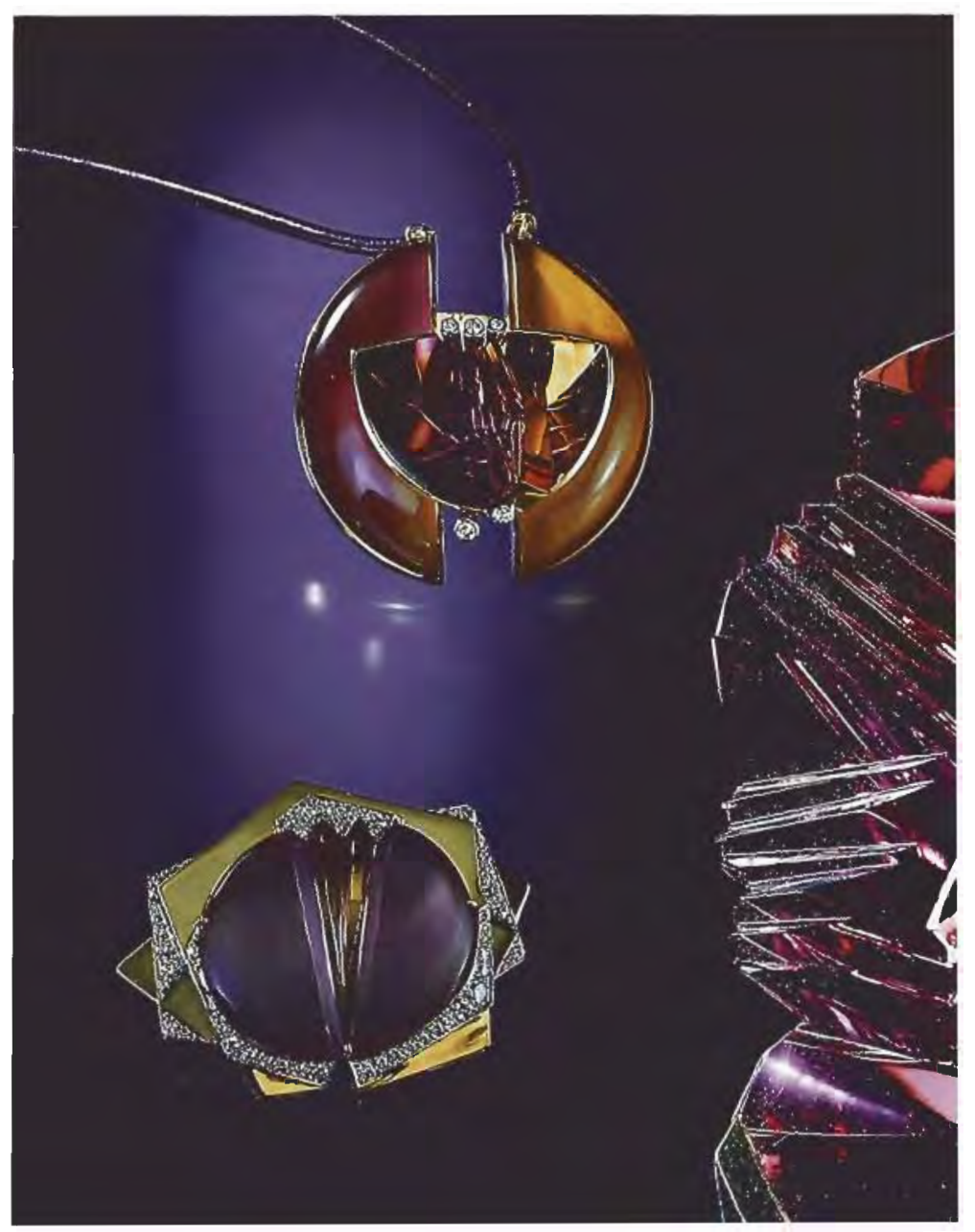




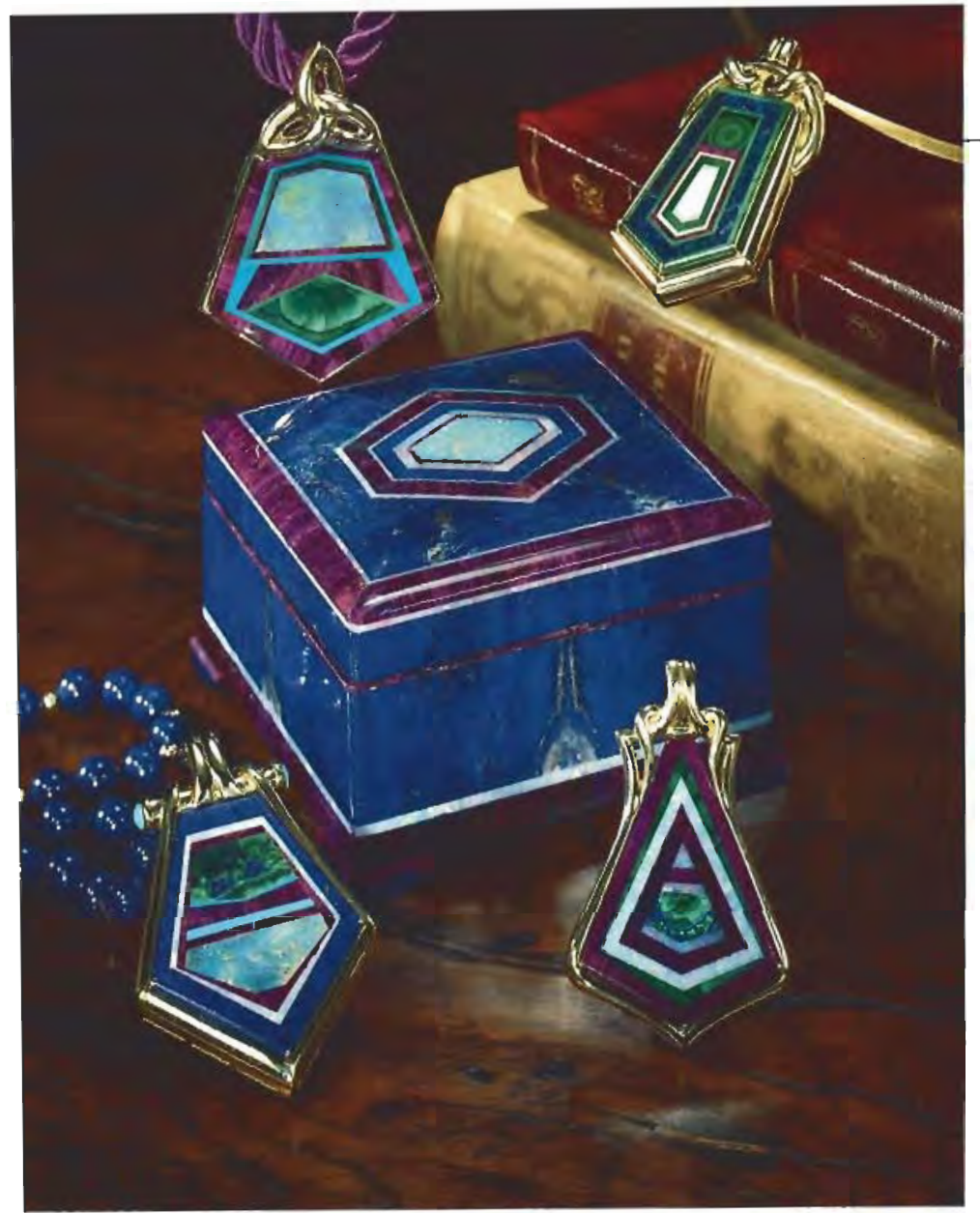

Figure 7. These four pendants and box are excellent examples of contemporary intarsia. Lapis lazuli, malachite, opal, turquoise, and sugilite are precisely cut and inlaid to produce these beautiful pieces. Intarsia by Nicolai Medvedev, goldwork by lanet Vitkavage. Pieces courtesy of E. F. Watermelon Co.; photo (C) Harold et Erica Van Pelt.

As the '80s progressed, cabochon-cut stones were used more frequently in jewelry (see figure 1). New variations appeared, with names evocative of their shapes: bullets, tongues, sugarloafs, and bufftop baguettes. Cabochon-cut rubies, emeralds, and sapphires, rarely seen in jewelry prior to the ' 80 s, also became very popular. A number of jewelry manufacturers worked directly with cutters to create custom-cut gems to suit a specific design. Gemstones were also worked into mosaics in a variety of applications. Intarsia saw a revival in jewelry and objets d'art, too (Elliot, 1986; figure 7).

Crystal "Fever." The end of the 1960s marked the "dawn of the Age of Aquarius," and the corresponding revival of many esoteric schools of thought. One of these philosophies, crystal consciousness, had a definite impact on the gem and jewelry trade in the 1980s. Lore regarding the spiritual and healing powers of gemstones, particularly in their original crystal form, attracted many followers. In 1986, crystal consciousness was stimulated by the publication of Shirley MacLaine's book Out on a Limb, in which she promoted the metaphysical properties of gemstones ("Catering to today's crystal craze," 1988). Crystals of all sorts, but particularly quartz, were fashioned into jewelry. Small clusters of crystals or slices of geodes were also incorporated into "wearable art" (Edelstein, 1989b). Although the actual fad for crystal jewelry was shortlived, the residual interest it focused on gems and jewelry was felt throughout the industry.

\section{METAL TRENDS OF THE 1980s}

The decade also saw a number of changes in the use of precious metals for jewelry. Fashion shifted from dainty and delicate, where the show of metal was minimal, to strong and assertive, where precious metals made a powerful statement.

Gold was the most popular metal, but price fluctuations affected the way it was used. For example, fashion was dictating the "big" look in jewelry just as goid prices began to climb. The use of hollow chains and electroforming techniques allowed a more massive look without excessive weight. The more affordable metal, silver, also made a comeback; the "big silver" look was often set with amethyst and blue topaz, as well as cubic zirconia, in bright pinks and blues as well as colorless.

Colored gold alloys also came back into vogue, and tri-color gold (yellow, white, and rose) was a major trend in all types of jewelry. An interest in the look of dark metal led to experimentation with alloys, including ones for blue and black gold that proved to be brittle and hard to work with. Ultimately, the dark metal look was provided by the use of surface-coloring techniques such as patination (antiqueing) and enameling in opaque black and in rich jewel-toned reds, blues, and greens (figure 8).

Platinum, traditionally reserved for important high-end pieces, began to be used more extensively throughout the industry. To make this metal more accessible to a larger market, jewelers began to combine platinum with gold to provide richness and a pleasing visual contrast.

Other, nontraditional metals also appeared in 
jewelry of the '80s. Titanium, developed for use in the aerospace industry, was found to be a light, strong metal that could be anodized to a variety of vivid colors. It was not widely used, however, and was incorporated more as an accent metal rather than for entire pieces. Tungsten carbide, also from the aerospace industry, was used for watches, while stainless steel cable, occasionally rhodium plated, was worked into a variety of bracelets, neckwear, rings, watchbands, and cufflinks, primarily for men. Many of these pieces were augmented by gold findings in the form of tiny screws for the industrial "high-tech" look, or toggle clips for the nautical effect. Cabochon-cut sapphires or flushset melee diamonds were sometimes added as well.

During the 1980s, the U.S. customer developed a greater interest in higher-karat gold, which traditionally has been preferred in Europe and Asia. With the emphasis on high-karat gold alloys, there was also an interest in making jewelry of $24 \mathrm{~K}$ gold. As a solution to the softness of pure gold, the World Gold Council (formerly Intergold) sponsored the development of a new alloy, 990 gold, that incorporates $1 \%$ ' titanium with $99 \%$ gold. While this alloy satisfies the Asian standard for pure gold 199\% gold, $1 \%$ impurity), it has the durability of a much lower karatage (Tasker et al., 1987). "Nine-ninety gold" is still in the experimental stages, however, and is not yet in widespread use.

Although the great majority of settings in the jewelry market of the ' 80 s were cast, a number of goldsmiths experimented with forming and working metals. Borrowing from jewelry styles of the 1940s, metals were folded, pleated, ruffled, and sculpted to imitate textiles and give the appearance of having been woven or formed into intricate lace or mesh. Texturing of metals was explored further during this period: Against bright polished gold, matte, brushed, and satin finishes provided a softened effect (figure 9), while reticulated, "distressed," and crystallized finishes gave a strong visual impact to artistic, modern pieces (Kremkow, 1988). Bright-cutting, or diamond-cutting, was another surface texture that was most commonly seen on mass-produced gold jewelry designed for the popular market. Stamped textures, imitating natural surfaces such as basket weave, crocodile skin, or leaves and scattered flowers, were also used to enhance the bold metal look of the '80s.

Exhibitions of ancient and antique jewelry awakened a new appreciation for early metal-

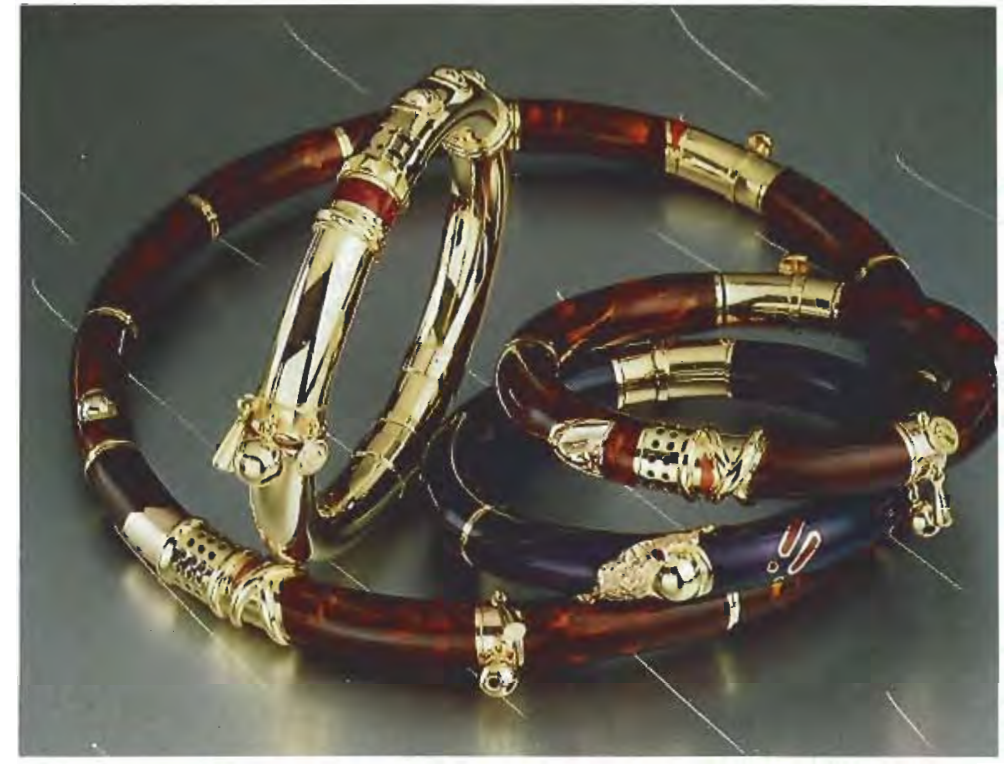

Figure 8. Opaque and jewel-toned enameling was one of several surface-coloring techniques of the 1980s. The "Metropolitan Collection" of four $18 \mathrm{~K}$ gold bangle bracelets and a collar necklace, courtesy of the Italian firm La Nouvelle Bague, strikingly demonstrate this.

Figure 9. Texturing of metals was a popular ' $80 \mathrm{~s}$ trend. Here, $18 \mathrm{~K}$ gold with a soft brushed finish is contrasted against pavé-set diamonds and highly polished gold in this elegant collar necklace. Courtesy of Henry Dunay. 
straight-line diamond bracelet slipped off during a televised tennis match and she stopped to pick it up. When later interviewed about the incident, she referred to it as her "tennis bracelet" (R. Frankel, pers. comm., 1990|. Toward the end of the 1980s, some jewelers offered "jackets" for tennis bracelets in the form of a wide clasp-on bangle designed with a channel into which the tennis bracelet could be slid and secured. Straight-line bracelets of colored stones were also popular, with and without the addition of diamonds. "Rainbow" bracelets and necklaces, incorporating suites of calibrated colored stones, were further adaptations of this ' 80 s style.

Rings of the 1980s generally had a more substantial look. The diamond engagement ring, which continued to be the industry staple, adapted to contemporary trends. Matching engagement and wedding band sets incorporated more diamond melee as accent stones, reflecting the move toward bigger jewelry. Pavé- and channel-set diamonds became indispensable, and the shanks of rings gradually widened to accommodate them (see figure $1 \%$. The decade started with the immensely popular, straight channel-set eternity - now called "anniversary" - ring. Toward the mid-1980s, however, channel settings began to follow more curvilinear designs, bending around the center stone, for example, or coiling in a graduated loop. These designs demanded precisely calibrated cut diamonds in straight and tapered baguettes as well as the new square-cut brilliants (figure 11).

"Stackable" rings were also updated for the '80s.

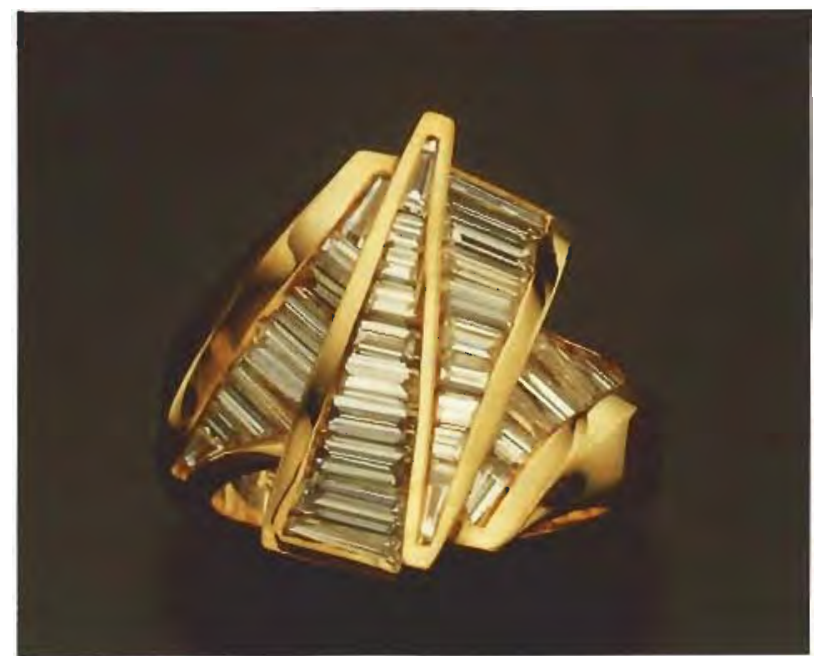

Figure 11. Larger, more substantial rings with channel-set baguette diamonds were very popular with the '80s woman. This $18 \mathrm{~K}$ gold ring is a 1989 Diamonds of Distinction award winner. Courtesy of Nova Stylings, Inc.

Sold individually, but designed to be worn in groups, these rings were usually produced in the same style but with contrasting gems, that is, one ring set with rubies, one with sapphires, and one with emeralds (see figure 1). A different type of stackable ring offered a variety of stones set in complementary styles that would "nest" neatly together, giving a variety of looks depending on how they were "stacked" on the finger.

During the 1980s, coins were seen more commonly in jewelry (figure 12). Many countries

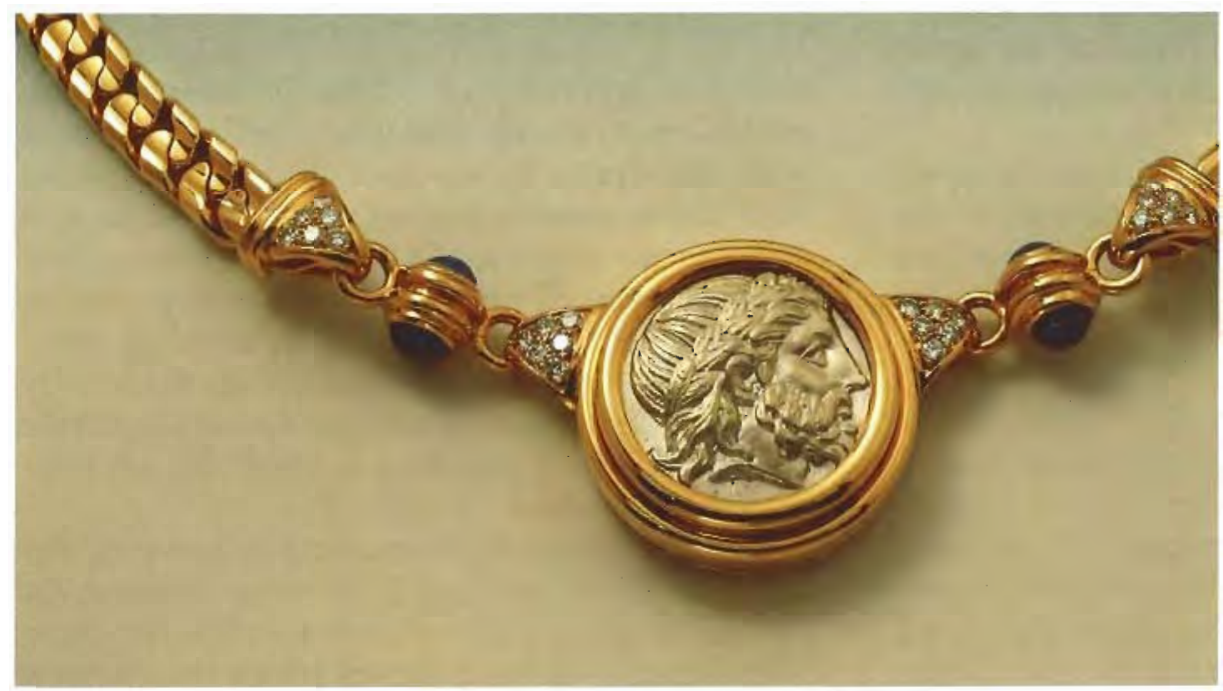

Figure 12. Antique and modern coins were popular in ' 80 s jewelry for both men and women. This ancient coin is bezel set in $18 \mathrm{~K}$ gold and accented with pavé-set diamonds and cabochon sapphires. Courtesy of Bulgari. 
issued newly minted gold, silver, and even platinum coins, examples of which appeared primarily as pendants but in other forms of jewelry as well. Ancient coins were also used in a variety of jewels. This trend may have been promoted by the consumers' increased exposure to ancient and antique jewelry through exhibitions and auctions as well as foreign travel.

The most notable innovation for necklaces in the '80s was the torsade. Several strands of freshwater pearls or gem beads were twisted and fastened, frequently with an ornate clasp in front (see figures 1 and 4). Also popular was the collar necklace or choker. Reminiscent of ancient Celtic torques, these close-fitting necklaces were designed to nestle in the hollow above the collarbone (see figure 9). Styles ranged from simple, sculpted, flexible gold links to elaborate works of art, rigid collars encrusted with colored gems, pearls, and pavé-set diamonds.

Brooches and pins made a comeback in fashion during the '80s. Overall, the look for brooches was large: a way to make a powerful statement. Long bar brooches were also popular worn vertically on jacket lapels, or on the shoulder of a dress, while smaller pins were often worn in groups.

In this decade of innovation, a number of unusual materials made their appearance in jewelry. As a contrast to the rigidity of metal and gems, some jewelry designers used a thick cord of woven silk, black leather, or even black rubber tubing, with gold clasps and massive, gem-set pendants. Another petrochemical product, acrylic plastic, was set with a variety of faceted transparent gemstones in jewelry. Although plastics of various types have been used for some time in costume jewelry and by avant-garde jewelers as "gem" materials, this decade saw its first use as a mounting for precious gems.

Watches were enormously popular for both men and women. They ranged from expensive creations, with jeweled casings and faces of fine lapis or other opaque gem materials, to inexpensive plastic "designer" styles.

Trends in Antique Jewelry. The 1980s saw a heightened interest in antique and period jewelry, to which the prominent auction houses contributed greatly. Previously dominated by dealers and a select group of collectors, auctions are now attracting more private clients. The quiet stream of private buyers became a torrent in 1987, when

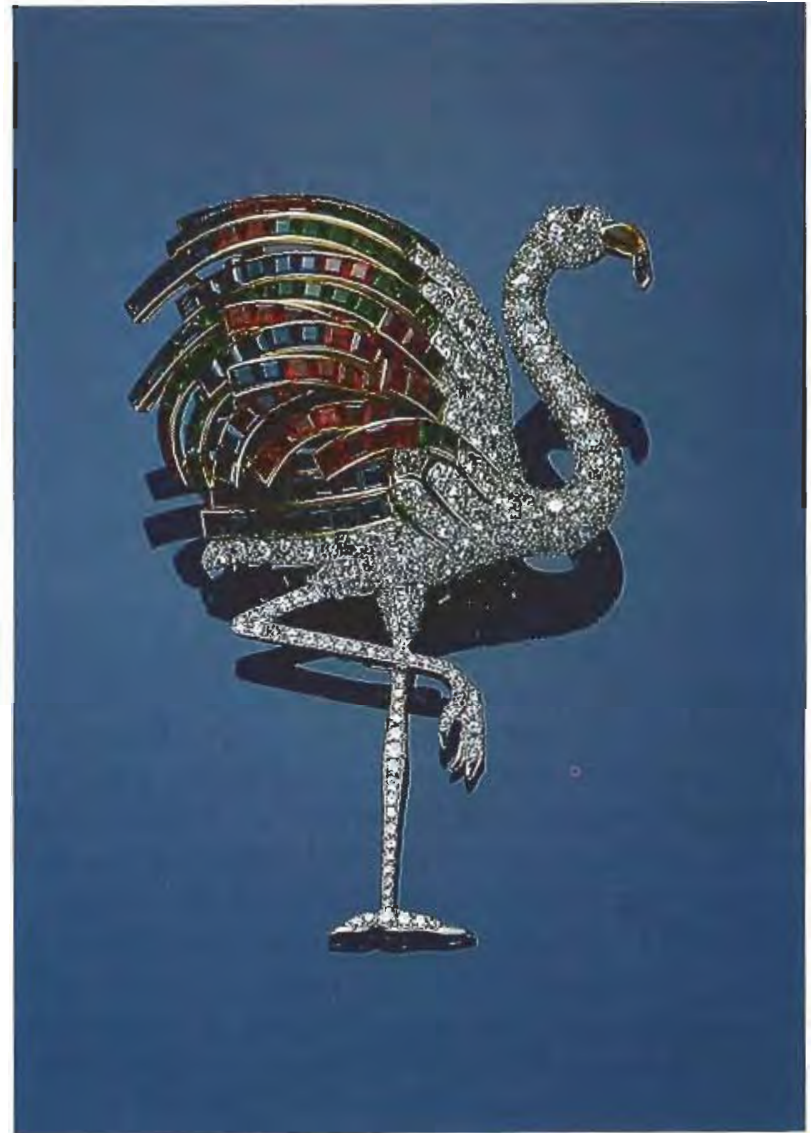

Figure 13. Created by Jeanne Toussaint for Cartier in 1940, this flamingo brooch from the collection of the Duchess of Windsor was auctioned by Sotheby's in 1987. Set in platinum and gold with rubies, emeralds, sapphires, diamonds, and citrine, the brooch was valued at $\$ 189,000$; it sold for $\$ 806,667$. Photo courtesy of Sotheby's, New York.

Sotheby's sold the jewels of the Duchess of Windsor in Geneva. For the first time, jewelry associated with British royalty was auctioned, and the media blitz had worldwide impact (Shor, 1988a). Experts at Sotheby's conservatively estimated the collection's value at $\$ 7$ million. When the gavel fell on the final lot, the sale totaled an amazing $\$ 50.3$ million. The excitement generated made the public aware that, through auction houses, a private individual could purchase a small bit of welldocumented history (figure 13).

Well before the Windsor auction, however, the auction houses noticed a growing demand for authentic antique and period jewelry. Art Nouveau's fanciful and naturalistic jewels were in favor 
initially, but these were soon eclipsed by the geometric precision of Art Deco that was more in keeping with the high-tech '80s (figure 14). "Retro" jewels - from the 1940s and early 1950s - became popular in the last half of this decade, while Victorian and Edwardian pieces also strengthened in sales. To satisfy the expanded market for these jewels, contemporary manufacturers began to produce exact replicas and close imitations. Modern designers not only used ancient metalsmithing techniques, as discussed earlier, but they also revived ancient and antique styles (see figure 1).

\section{DESIGNERS OF THE 1980s}

It would be impossible in this brief overview to mention each of the talented jewelry designers worldwide who deserve recognition. However, it is important to note the contributions made by certain designers or design houses to jewelry styling in the 1980s. This section will discuss the general styles of jewelry from various countries and regions, and give examples of one or two designers from each whose innovations had an impact on jewelry trends during the decade.

"Name" Designers. In the 1980s, "designer label" consciousness extended beyond clothing fashion to other luxury items such as cars, watches, and jewelry. A number of new designers emerged, including some whose well-known names, coupled with their talent, brought them immediate acceptance. Paloma Picasso was invited to work under the Tiffany aegis, and her name was attached to a line of bold jewels that use large, richly colored tourmalines, citrines, amethysts, garnets, and kunzites (see cover, Gems \&) Gemology, Summer 1987). Bezel-set simply in the center of a heavy neck chain or a large gold ring, the gem itself is the focus in her jewelry, which can be credited with helping to broaden consumers' acceptance of colored stones other than the ubiquitous ruby, emerald, and sapphire in high-fashion jewelry.

Another designer, with a richer heritage in jewelry design, is known as Marina B. As the daughter of Constantine Bulgari, she was raised in the exotic world of haute joaillerie. From an early age, she worked closely with her father and learned the exacting technicues of jewelry design and manufacture. After his death, Marina broke away to start her own jewelry company, with the condition imposed by the family business that she not use the name Bulgari. Thus, as Marina B, she

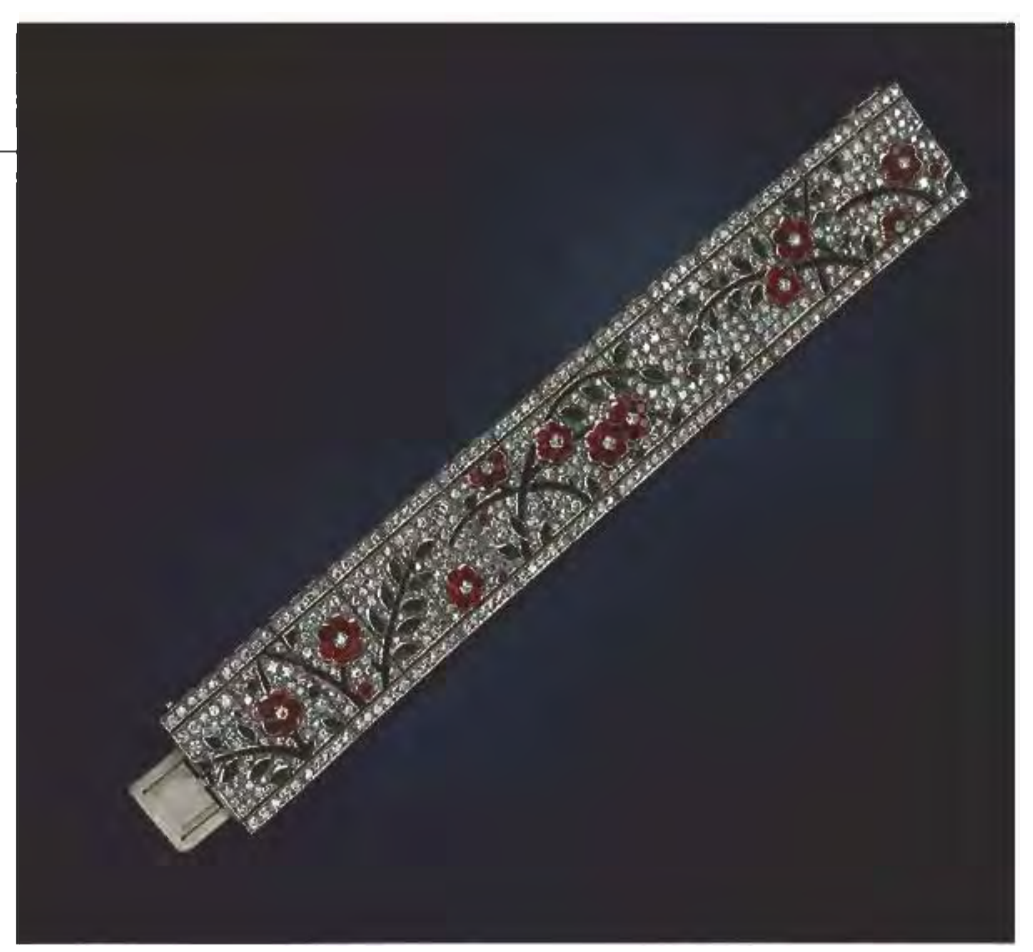

Figure 14. "In a Persian Garden" is the name of this authentic Art Deco bracelet offered at auction by Christie's in 1988. Platinumarticulated links are set with diamonds, emeralds, and rubies, further enhanced by black-enameled flower sprigs. Photo courtesy of Christie's, New York.

opened her first showroom in 1979, and throughout the '80s developed her own recognizable style of distinctive jewels. Heart-shaped figures without the cleft are one of her signatures and appear as the motif in snug chokers and earrings. Her jewelry is comfortable and ingeniously designed, such that in many pieces the central stones can be removed or their backgrounds can be changed (Seebohm, 1987; figure 15).

United States. In the U.S., there were several exceptional artists whose work during the past decade influenced jewelry styles internationally. Among these, New York designer Henry Dunay captured European attention in the early 1980s, when he was one of the first U.S. designers to exhibit at the Basel Jewelry Fair (Edelstein, 1989a). His sculptured and "faceted" gold jewelry led to other textured finishes such as matte or brushed gold. Dunay also introduced a line of braided gold jewelry that extended to men's bracelets and cufflinks as well as to women's necklaces and earrings. His motifs take the form of plump, rounded squares, soft knots, "candy twists," and shell-like whorls, all of which involve a contrast of textured and smooth finishes, some appearing to be tied with thin wires of polished gold (figure 16). 


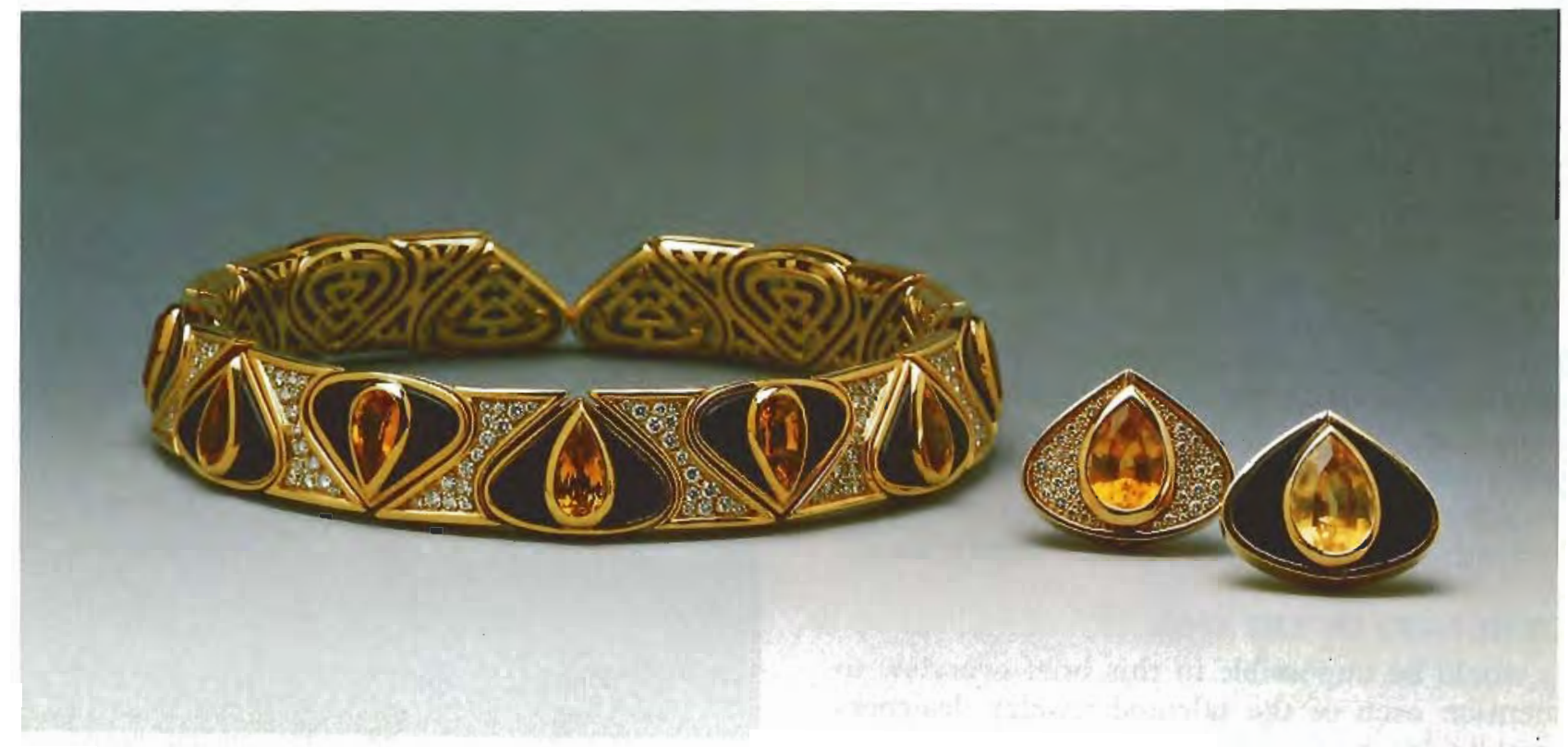

Figure 15. This versatile choker and earring suite-of yellow sapphires, black onyx, and pavé-set diamonds mounted in $18 \mathrm{~K}$ gold-shows the signature heart-without-a-cleft motif that is prevalent in Marina $B$ jewels. The earrings are designed so that the background can be changed from pavé-set diamonds to black onyx. Courtesy of Marina $B$.

Frequently, Dunay enriches his jewels by pavé setting them with diamonds, a technique at which he excels. Subtle and understated, Dunay's jewels have led the way for other American designers in the international market.

The Los Angeles-based company Nova Stylings became known for their innovative channel-set baguette diamond jewelry, a major fashion statement of the 1980s. Round diamonds in channel settings were characteristic of jewelry in the late '70s, but taking calibrated baguettes and channel setting them to follow lyric, tapering curves in a ribbon of light, was a technique new to the '80s. Nova Stylings president Martin Gruber and designer Akiko Wakabayashi have been consistent winners of the Diamonds International and Diamonds Today competitions with jewelry incorporating this technique (figure 17).

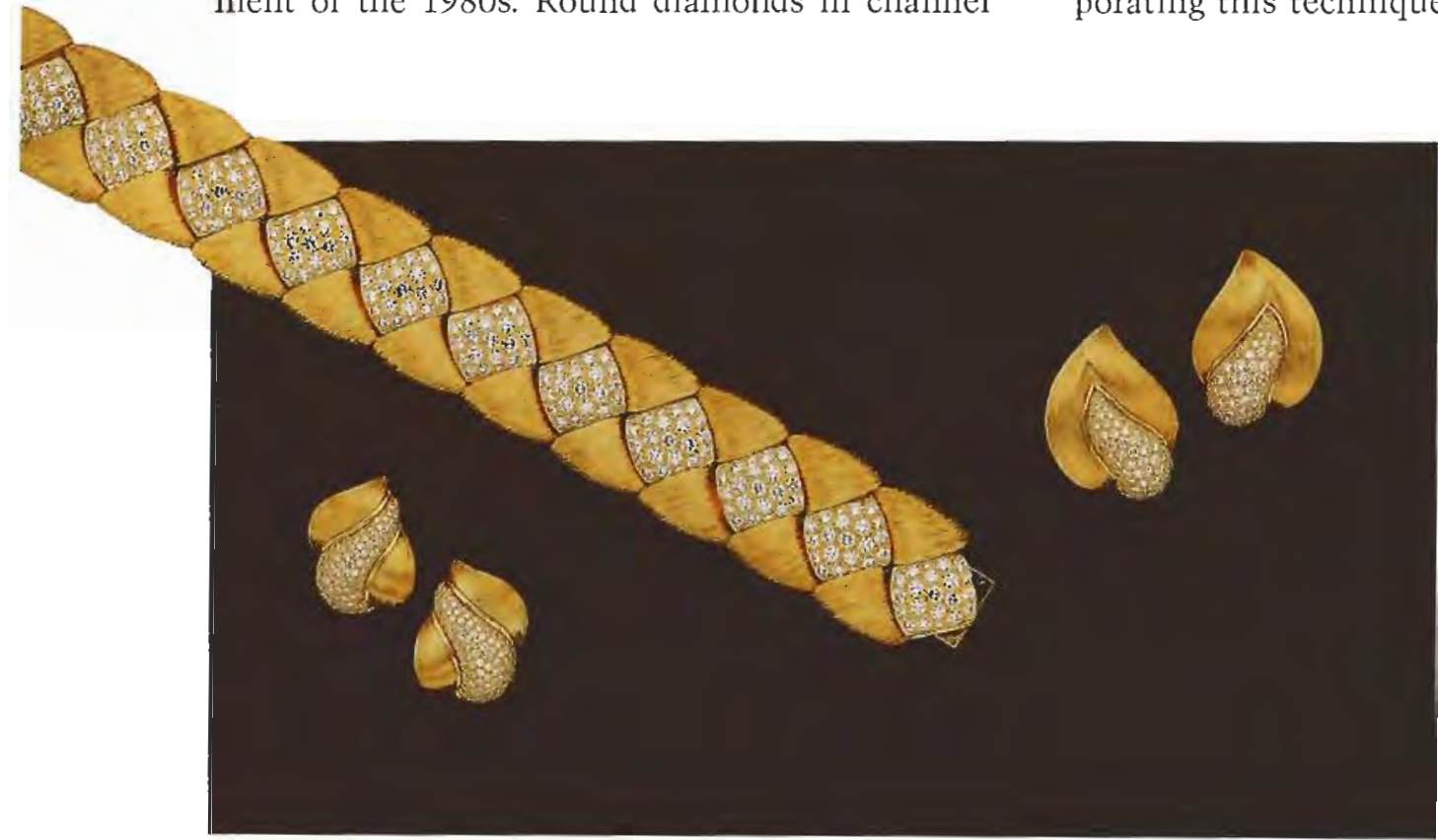

Figure 16. Plump braids, "candy twists," and turbans are frequent motifs in Henry Dunay's jewels. The contrast of textured $18 \mathrm{~K}$ gold and pavé-set diamonds became a popular trend in the 1980s. Courtesy of Henry Dunay. 
Italy. Italy continued to be the largest producer of gold chains during the 1980s. Dozens of Italian companies produced an endless variety of chains, the links becoming more complex and the chains more substantial as the decade progressed.

Many companies in Italy also produced exquisite jewelry. Among these is the firm of Bulgari. Although they have been fine jewelers for generations, many of their designs became signature looks in jewelry fashion of the '80s. With classic simplicity, Bulgari bezel set ancient coins and suspended them from a smooth heavy chain, tastefully reviving this style (see figure 12). Bulgari is also known for their distinctive necklaces of elegant design in a style drawn from ancient Rome. Matched pearls, rubies, emeralds, or sapphires are bezel set and accented with pavé- and channel-set diamonds. These slender necklaces are frequently designed in suites with matching earrings and rings.

Great Britain. Generally speaking, British jewelry in the 1980s followed conservative, traditional lines. Much of the jewelry trade in England was focused on antique and period jewelry from the turn of the last century. However, two exceptional British jewelers attained worldwide recognition during this decade, if for very different reasons.

Laurence Graff became known for dealing in large stones of the finest quality, set in stunning jewels. In 1984, Graff unveiled the "Imperial Blue," a 39.31-ct pear-shaped diamond that he claimed was the world's largest flawless fancy blue. He had it set in a simple pendant surrounded by round brilliants suspended from a rivière of pear-shaped diamonds. Later that same year, he presented the "Empress Rose" as the largest (72.79 ct) flawless pink diamond in the world (Vassiltchikov, 1988). Although these rare jewels are accessible only to a very select few, they nevertheless helped whet the public appetite for fancy-color diamonds and fine colored stones.

Elizabeth Gage gained attention by designing highly unusual jewelry in a creative blend of ancient Roman and Renaissance styles (see figure 4). Her unique jewels frequently combine antique coins, carved gemstones, or 18th-century glass intaglios with baroque pearls, diamonds, and a variety of colored stones. Some of her creations are further ornamented with translucent enamels and embellishments to the metal surface. Most of Gage's pieces are large and dramatic: Rings are

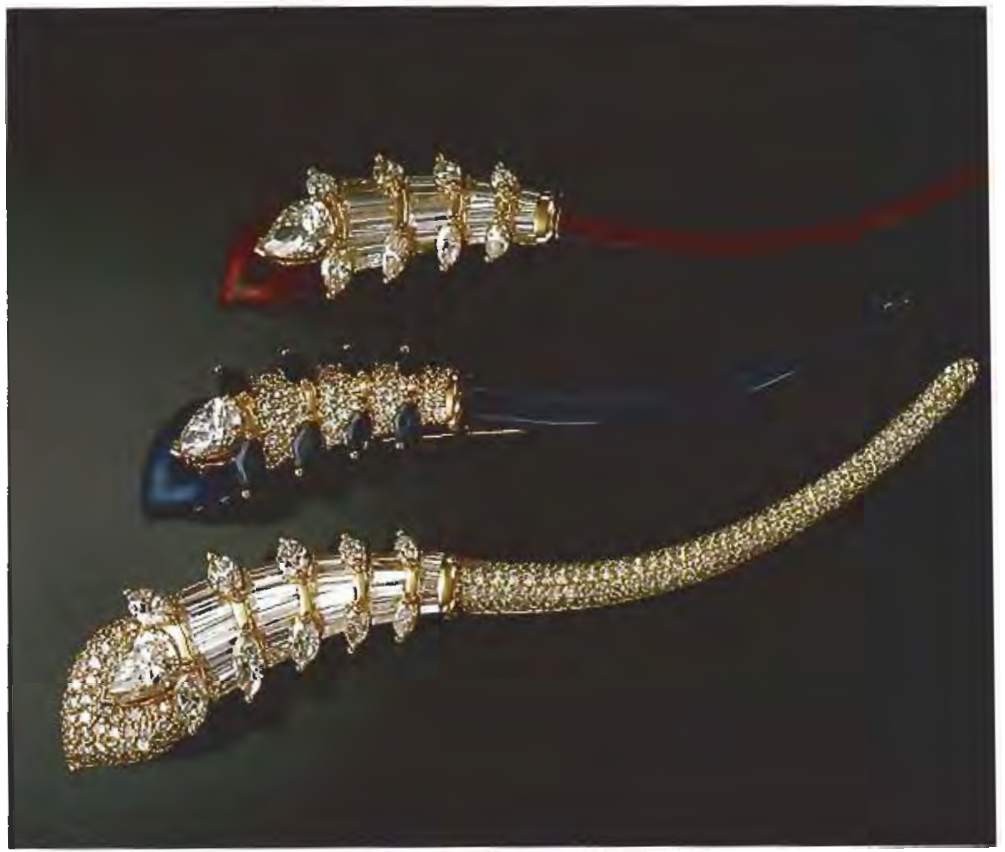

Figure 17. The "Diva Pin," designed by Akiko Wakabayashi, was an award winner in the 1989 Diamond Today competition. Shown here in three possible variations, the pin is composed of prong-, channel-, and pavé-set diamonds and sapphires mounted in $18 \mathrm{~K}$ gold, with blue and red enamel. Courtesy of Nova Stylings, Inc.

often high domed, featuring cabochon-cut stones or sculpted gold, and can be as much as an inch wide; brooches are often two to three inches in diameter, of quatrefoil shape with spiral points, sometimes terminating in a lustrous pearl (Watts, 1984). Gage exemplifies the trend of "interpretive" jewelry that became popular again in the 1980s (figure 18).

Germany. German jewelry design of the last decade was quite different from the traditional styles being produced in most European countries. Overall, the look was more avant garde. Several innovative techniques developed for the Germany company Niessing by designers Matthias Monnich, Simon-Peter Eiber, Christian Kube, and Norbert Muerrle have since been adopted by many other jewelers worldwide ("Das Niessing Konzept," 1987). Niessing is recognized as the first company to "marry" gold and platinum, fusing it without solder. Jewelry made by this process usually has a brushed or matte finish to help define the contrast between the two metals. In 1984, Niessing also 


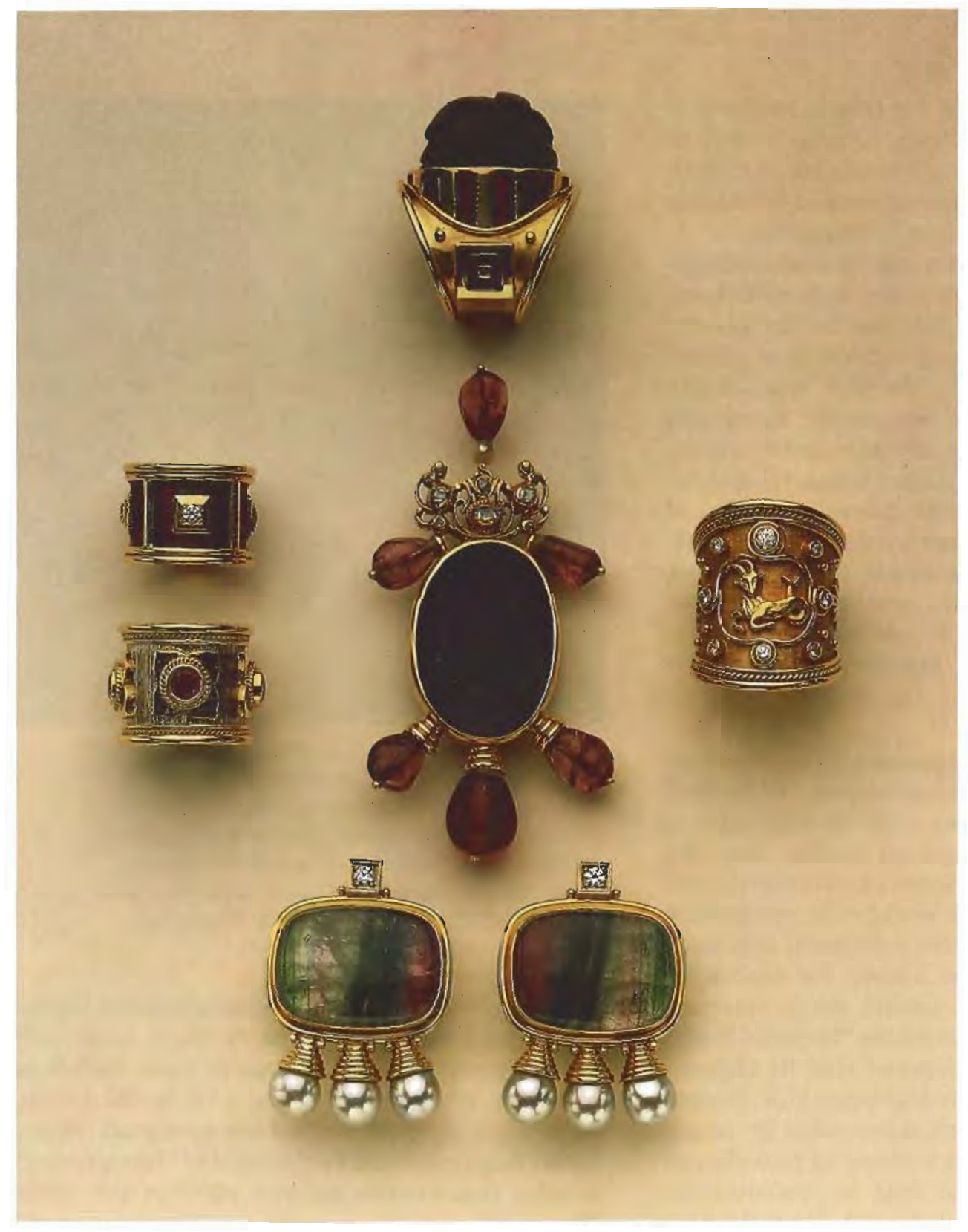

Figure 18. During the 1980s, English designer Elizabeth Gage focused on interpreting antique styles. Clockwise from the top (all set in $18 \mathrm{~K}$ gold): a carved horn scarab ring with red enamel, zodiac ring with bezel-set diamonds, cabochon-cut bicolored tourmalines bezel set in earrings with diamonds and cultured pearls, and two "templar" bands-one set with rubies and the other set with diamonds and using red enamel. The brooch in the center contains an antique glass intaglio, surrounded by tourmalines in spiral points, antique diamonds, and one pearl. Jewelry designs (0) Elizabeth Gage, Ltd.

introduced "iris" gold alloys: A special technique produces $18 \mathrm{~K}$ gold that can exhibit up to seven different "colors," graduating from deep yellow to white, in the same piece (figure 19). Niessing designers are also credited with developing the tension setting of diamonds in platinum. They use the "spring" of the metal to hold the stone rather than a structurally fixed seat, so the stone appears to float between the two arms of the ring shank in what they call a "pre-stressed ring" (Schmager, 1987; figure 201. Another Niessing development popularized in jewelry of the late 1980s is the flush setting of round melee diamonds in a "polka-dot" pattern on the shanks of matte-finished gold and platinum rings, and on bracelets, necklaces, and brooches.

Spain. Otherwise conservative in jewelry design, Spain produced one particularly distinctive ' 80 s artist. Although several jewelers worldwide have incorporated sculptural details into their work, few have produced such sensuous, streamlined figures as Carrera y Carrera. Languid, stylized women wrap their long, slender limbs around a gem in a gentle embrace to make a delicate but striking pendant or ring. Other motifs include 


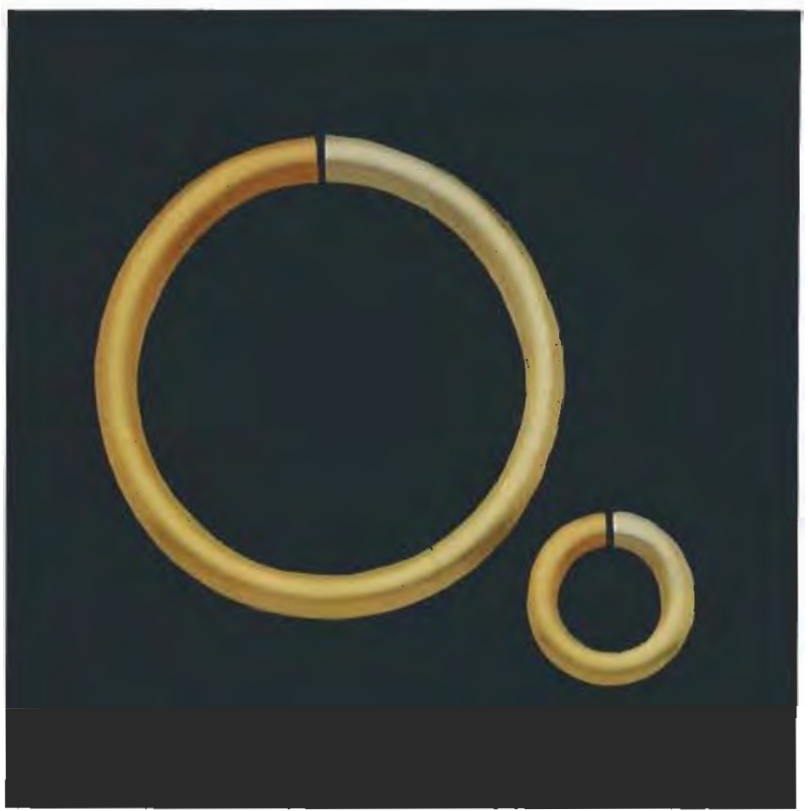

Figure 19. This "iris" gold bangle bracelet and ring illustrate the gradual shading from yellow to white that characterizes this unusual alloy. Courtesy of Niessing, Ltd.

$$
\therefore
$$

Figure 20. The "pre-stressed ring" was a new method of diamond setting developed in the early 1980s by Niessing, Lid, of Germany. The tension of platinum is used to secure the stone in such a way that the diamond appears to be lightly suspended in air. Courtesy of Niessing, Ltd.

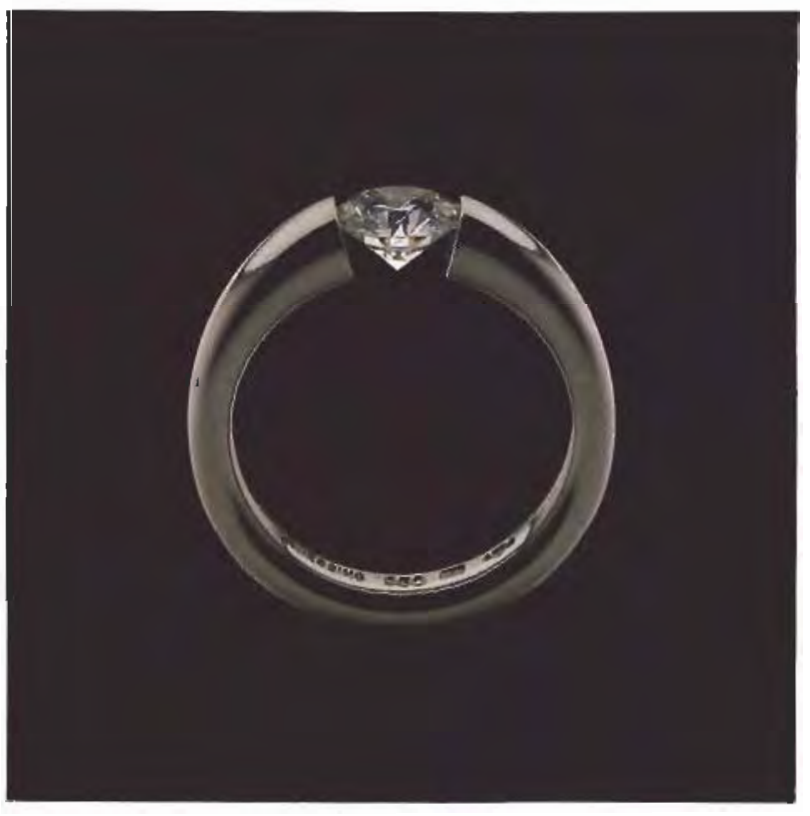

horse heads, appearing to race with the wind, or sleek panthers stalking their prey. Many of these motifs are used to frame a plain, unnumbered watch face. Combining matte and shiny surfaces that are occasionally accented with diamonds, Carrera y Carrera's jewels have stimulated many imitators (figure 21).

France. For centuries, France, particularly Paris, has been the center for high fashion in jewelry. The large French jewelry design houses such as Cartier, Van Cleef \& Arpels, and Boucheron were innova-

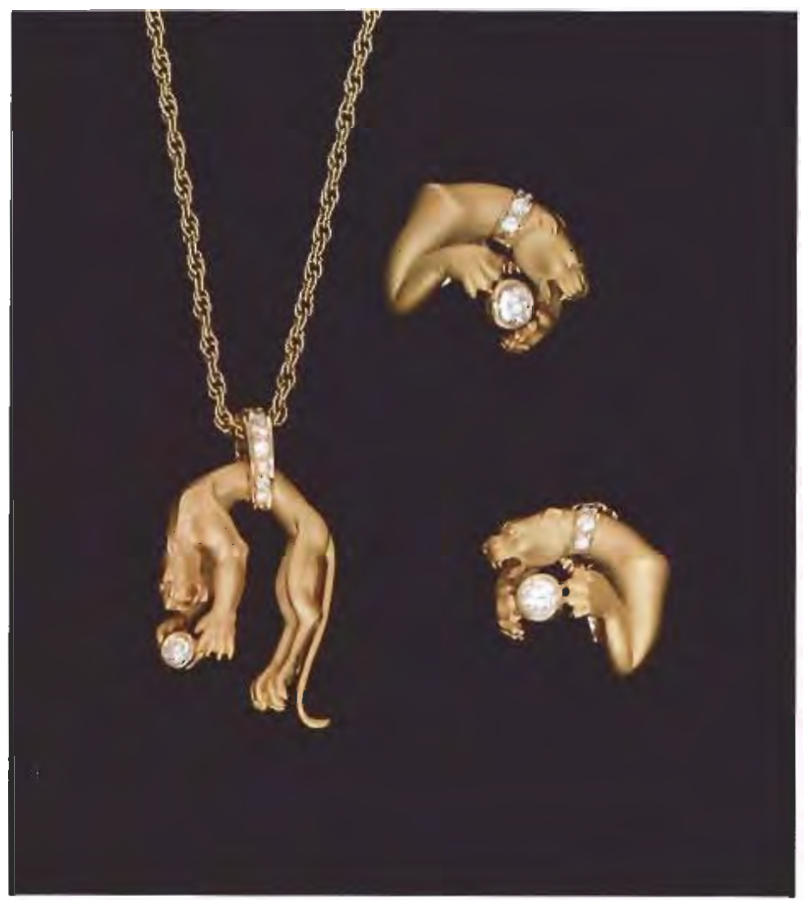

Figure 21. These sculptured panthers, set in $18 \mathrm{~K}$ gold with diamonds, are characteristic of the Spanish firm Carrera y Carrera. Courtesy of Carrera y Carrera.

tors during the first half of this century, but in recent years have tended to be more conservative. There are exceptions, of course: Cartier was one of the first jewelers to use stainless steel in a line of men's jewelry, and Boucheron was at the forefront in the evolution of collar necklaces. In the early 1980 s, Boucheron began to design parures of closefitting collar necklace, earrings, and rings made of carved rock crystal set in gold with diamonds, sapphires, and rubies. Van Cleef \& Arpels, stimulated by the renewed interest in period jewelry that 


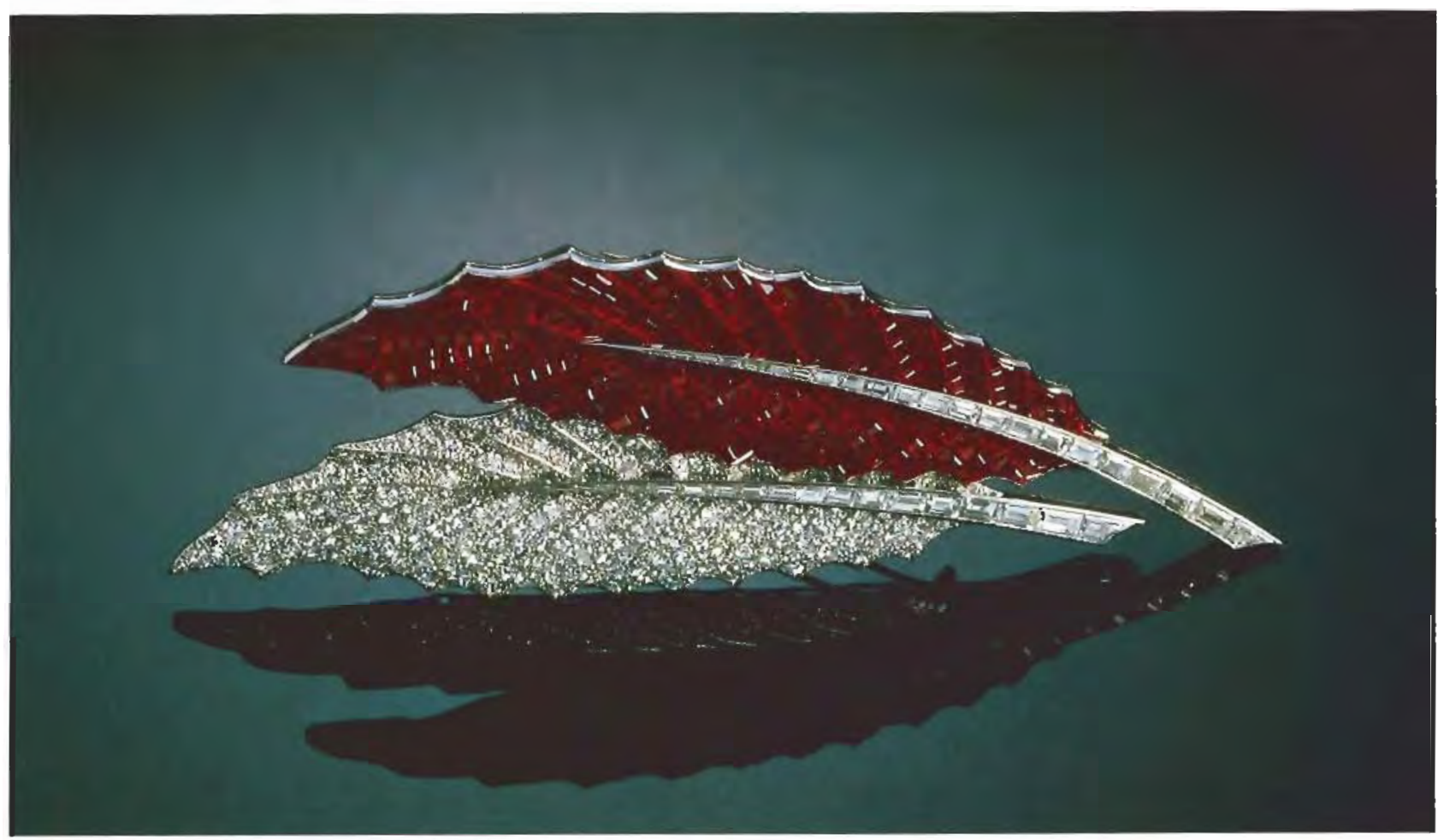

Figure 22. This 1936 ruby, diamond, and platinum "holly leaf brooch" is one of the first invisibly set jewels made by Van Cleef et Arpels. Sold at the 1987 auction of the Duchess of Windsor's jewels, the piece helped revive interest in invisible setting during the 1980s. Photo courtesy of Sotheby's.

swept the ' 80 s, once again began using the invisible settings they had developed in the late 1920 s (figure 22). This exacting technique involves setting precisely calibrated sapphires, rubies, and, rarely, emeralds, in hidden mountings so that no metal is visible between the stones. The popularity of invisible settings during this decade has prompted many jewelry manufacturers to imitate the style, but none can match the originals for design and execution.

Japan and the Pacific Rim. Japan became a strong presence in the gem and jewelry market of the 1980s. As the yen strengthened against the dollar, the Japanese became important consumers of highquality diamonds and platinum, especially for engagement rings and other jewelry gifts associated with weddings. Motivated by this demand, Japanese jewelry designers developed a style that integrated Japanese tradition with modern Western culture. Stark color contrasts, with an emphasis on black and white, characterize their pieces. Black onyx, black jade, black lacquer, and black enamel are employed to provide a dramatic background for diamonds and pearls.

Other Asian countries along the Pacific Rim also experienced tremendous growth in their gem and jewelry industries. Major cutting operations in Thailand and Hong Kong were developed to meet the burgeoning trade in colored stones. These countries also expanded their jewelry manufacturing efforts to meet the growing demand for lowcost jewelry in the mass market, including replicas and imitations of fine European antique and period jewelry.

\section{CONCLUSION}

The 1980s made some interesting contributions to the evolution of jewelry design: new cuts for both diamonds and colored stones, new and different setting styles (channel-set baguettes, flush-set and tension-set diamonds, and modern adaptations of older techniques (invisible settings and bezel settings). There was also a new look to the precious metals used: Gold, platinum, and other metals were intermingled in the same piece, colored 
alloys of gold were popular again, and a variety of surface textures were revived and explored. At the same time, in this eclectic era, jewelry designs ran the gamut from antique and traditional to futuristic, from romantic to starkly modern, with myriad variations in between.

Looking into the '90s and the fast-approaching 21 st century, it is interesting to speculate on what changes will take place in jewelry fashion. Current trends suggest a number of possibilities. There will be a continued progression in the trend of unusual cuts for gems coupled with new and ingenious ways of setting them, following the sleek, modern look that developed in the late '80s.

Advances in technology will further facilitate the manufacturing arts. CAD-CAM (computeraided design/manufacturing) systems, for example, are successfully streamlining the large-scale manufacture of jewelry findings, and hold great potential for artistic applications as well.

Ease of travel and communication has made ethnic art more immediately accessible, and we may see new interpretations of cultural motifs and styles in jewelry.

Men will be wearing more jewelry in distinctive ways. Lapel pins for men are becoming larger and more interesting. Bola ties have graduated from their cowboy beginnings and are appearing in more contemporary form. Men's bracelets and rings, static in design for so long, are overdue for a new look. Earrings for men will probably never evolve past the single gemstone stud or small ring stage, although they may be sported by a greater number. Belt buckles for men are another jewelry item ripe for transformation.

Jewelry for women will expand on the present theme of versatility, giving women more jewelry accessories that can be worn with casual or business clothing as well as evening wear. Rings, bracelets, and earrings will stay large and impressive. Substantial brooches and collar necklaces will continue to grow in popularity. For evening, there will be more jewels worn in the hair. Overall, the look we are moving toward is sleeker: more compact and less cluttered. The gap between artist and manufacturer has been narrowing, and jewelry will undoubtedly reflect this by being less generic and more personalized. In the late 1980s, women were expressing more individuality in the way they wore jewelry and in the jewelry they chose. This trend will strengthen, and jewelers will strive to meet this by designing jewels that women can tailor to their own particular taste.

The steady expansion and development of the jewelry industry during the 1980 s will continue. It will be exciting to watch the progression of dazzling jewels that evolve as we enter the 21 st century.

\section{REFERENCES}

Ban on ivory trade gets final approval (1989) Los Angeles Times, October 18.

Catering to today's crystal craze \{1988| Jewelers' Circular-Keystone. Vol. 154, No. 2, p. 162-164.

Clever diamond cuts launched by the CSO (1988) Retail Jeweller, Vol. 26, No. 678, pp. 1, 8 .

Edelstein C. (1989a) How Americans designed their way to the top. Jewelers' Circular-Keystone, Vol. 160, No.9, Part II, pp. 39-44

$-(1989$ b) Shopping the craft fair altemative. Jewelers' CircularKeystone, Vol. 160, No. 9, pp. 30-37.

Eisman R., Hinge J. (1988) Consumer audit - The working woman solving the puzzle. Nutional leweler, Vol. 32, No. 11, pp. 50-74.

Elliot J. (1986) Contemporary intarsia: The Medvedev approach to gem inlay. Gems a Gemology, Vol. 22, No. 4, pp. 229-234.

Federman D. (1990) Modern leweler's Consumer Guide to Colored Gemstones, Van Nostrand Reinhold, New York.

Goebel M., Dirlam D.M. (1989) Polynesian black pearls. Gems e) Gemology, Vol. 25, No. 3, pp. 130-148.

Hofer S.C. (1985) Pink diamonds from Australia. Gems \&) Gemology, Vol, 21, No. 3, pp. 147-155.

Kane R.E. (1987) Three notable fancy-color diamonds: Purplish red, purple-pink, and reddish purple. Gems e Gemology, Vol. 23, No. 2, pp. 90-95.

Kremkow C. (1988) Fashion begins with the finish. Jewellery News Asia, No. 47, pp. 82-87.

Das Niessing Konzept (1987) Art Amea, 4th quarter, pp. 57-61.
Pearl sales up, imports down (1988) /ewelers' Circular-Key'stone, Vol. 154, No. 10, p. 57.

Schmager S.M. (1987) Interview with Jochen Exner. Swiss Watch e) lewellery lournal, June, pp. 763-766.

Seebohm C. (1987) B is for beautiful. Connoisseur, Vol. 219, No.902, pp. $59-65$.

Shigley J.E., Koivula J.I., Fryer C.W. (1987) The occurrence and gemological properties of Wessels Mine sugilite. Gems $\left.\uplus_{t}\right)$ Gemology, Vol. 23, No. 2, pp. 78-89.

Shor R. (1988a) Auction fever fuels gem market. Jewelers' CircularKeystone, Vol. 154, No. 12, pp. 132-135.

- (1988b) De Beers: 100 years of market control. Jewelers' Circular-Keystone, Vol. 154, No. 3, pp. 176-196.

— (1989) The diamond trade: It's a different world now. Jewelers' Circular-Keystone, Vol. 160, No. 9, Part Il, pp. 53-59.

Tasker A.M., Beilstein K, Reti A. \{1987) Something new under the sun: 990-gold-a hard, high karat alloy. American Jewelry Manufacturer, Vol. 35 , No. 8 , pp. 56-66.

Thomas S.A. (1987) Bernd Munsteiner: Flights of fantasy. In Focus, Spring 1987, pp. 12-14.

Vassiltchikov N. (1988) Graff unmistakably. Indiaqua, Vol. 49, No 1, pp. $79-81$.

Watts J. (1984) A life of their own. Connoissewr, Vol. 214, No. 872, pp. $122-125$.

Weiss R. (1988) Glass-eating turtle fills unique niche. Science News, Vol. 133 , No. 5 p. 70 . 